\title{
Education and conflict: From emergency response to reconstruction and peacebuilding
}

\author{
Clementina Acedo
}

Published online: 12 May 2011

(C) UNESCO IBE 2011

Education for All (EFA) was a promise made by 155 countries and about 150 representatives of humanitarian organizations in Jomtien, Thailand in 1990. This promise was reiterated in Dakar, Senegal in 2000, where six broad goals and targets were set to be met by 2015 . In 2011, the international community is far from achieving these goals; yet, as the 2011 Global Monitoring Report shows, considerable efforts have been made and achievements are visible. For example, some of the poorest countries are doubling their primary enrolment rates and narrowing their gender gaps.

The articles published in this special issue on Education and Armed Conflict are based on selected background papers, which were commissioned for the 2011 EFA Global Monitoring Report. The 2011 report highlights one of the greatest barriers to reaching the EFA goals: conflict. Many countries suffer from continuous or spontaneous conflict, which creates unstable conditions for civilians, and particularly children, who are too often forced to leave behind the little education that they were receiving in order to escape from the conflict. Due to the nature of conflict, humanitarian efforts must, more often than not, focus on the immediate survival of victims, by providing shelter, water, food, and medical care. However, some of these conflicts are continuous, forcing people to live for years in temporary arrangements, where, without education, they may completely lose hope for a better future.

The Global Monitoring Report stresses that education is life-saving, especially for those living in conflict, and should therefore be treated as such in the humanitarian response. As Ms. Irina Bokova, Director General of UNESCO, expressed it at the official launch of the report in New York on March 1st, "education cannot remain the poor cousin of international efforts to manage conflicts". Providing education in a post-conflict context helps national reconstruction, in a different and more profound way than meeting only basic needs such as food, water, and shelter. Furthermore, an education that promotes human rights and civic values can go a long way in helping the next generation to work towards a self-sustaining and peaceful society. In fact, more often than not, it is the populations affected by conflict that demand an education so they can actively create a better future for

C. Acedo $(\bowtie)$

UNESCO IBE, P.O. BOX 199, 1211 Geneva 20, Switzerland

e-mail: c.acedo@ibe.unesco.org 
themselves and their children. For precisely these reasons, development aid must also focus on education once the conflict has ended, and provide the assistance for it to be used as a tool for national reconstruction. UNESCO has an important role to play in promoting the continuum from prevention and early response to long-term reconstruction and peacebuilding. This implies support to strengthening the education system, including teacher management and training, and curriculum reform.

In her introduction entitled "Education's hidden crisis: An overview of the 2011 Education for All Global Monitoring Report", Pauline Rose, guest editor of this issue and senior policy analyst on the EFA Global Monitoring Report team at UNESCO in Paris, ties together the essence of the selected papers authored by distinguished scholars and professionals and links them to the findings of the report. She also describes what the report recommends that the international community do to address the four failures identified in the report: protection, provision, reconstruction, and peacebuilding. She concludes that governments, rich and poor, must act together to address these failures in order to ensure progress towards EFA goals.

Graham Brown sets the tone of this issue with his article titled "The influence of education on violent conflict and peace: Inequality, opportunity, and the management of diversity". He emphasizes the impact that education can have on conflict, potentially instigating it. He argues that education can be an important factor in marginalizing particular groups; in this respect, he says, education becomes increasingly politicized in societies where conflict has become a normal state. He further discusses the roles that education can play in conflict dynamics: governments may force the dominant ethnic group's language on the education system and dismiss other local languages, or they may decentralize the education system, allowing for regional autonomy. He concludes that the relationship between education and conflict is a complicated one: education indirectly affects conflict through its interaction with other structural causes of conflict, such as the marginalization of ethnic or religious groups. He concludes that policy makers must take the various interactions into account in order to provide the most appropriate assistance and responses.

Adele Harmer, Abby Stoddard, and Victoria DiDomenico present a case study of the international aid being provided for education in conflict-ridden Afghanistan and Pakistan and the role it currently plays. They focus on the challenges faced by the international aid actors and the entire education systems that are the targets of violent attacks. The authors suggest a potential way to reduce the number of attacks: take a more community-based approach, decreasing both involvement with the government and association with international politics and the military. Furthermore, they suggest taking the cluster approach for education as a way to ensure humanitarian coordination in conflict-ridden areas, and to provide a method for accountability in such an unstable environment. The authors draw on evidence from recent research and quantitative analyses, as well as observations of actors in the field.

In her article, Rebecca Holmes discusses the role of social protection in supporting education in conflict-ridden areas. She defines social protection programmes as combining interventions in order to address "risk, vulnerability and chronic poverty". She continues by analyzing the issues related to funding, designing, and implementing such programmes in various country contexts, such as Afghanistan, Democratic Republic of Congo (DRC), Sierra Leone, Somalia, Nepal, Northern Uganda, and Pakistan. Holmes argues that education is both directly and indirectly costly in conflict areas and that therefore social protection programmes can help eliminate this barrier to education. 
Jeni Whalan presents a case study analysing the international aid given for education to Solomon Islands after the years of violent conflict (1998-2003) which plagued the islands. During this period, Solomon Islands suffered not only from the lack of an education system, but also from an almost complete state failure. Before the conflict began, the education sector had already been struggling, making its reconstruction a greater challenge. The Regional Assistance Mission in Solomon Islands (RAMSI) was set up, providing funding for the education sector, and opening the door to other international aid. Whalan discusses the effects of aid, and the positive outcome of strong government support, on the education sector.

The Rewrite the Future campaign was launched by Save the Children UK, as an initiative to prioritise quality education for children in conflict areas. Dolan and Ndaruhutse analyze the influences of this campaign and the challenges that this non-governmental organization (NGO) has faced in obtaining funding. In the current financial climate, the NGO has been forced to draw on several funding sources which tend to be unreliable and generally offer only short-term aid. The authors discuss the achievements of Save the Children UK, as well as the challenges which continue to negatively affect the implementation of programmes in conflict-ridden countries.

Lyndsay McLean Hilker presents the case of Rwanda, in which education played a dual role, both driving conflict and building peace. She begins by analyzing the role education had before the civil war (1990-1994) and the genocide (1994), and then analyzes the postgenocide situation. She argues that despite steady improvements since 1994, and the rebuilding of the education system, there are still elements and challenges which mirror the pre-genocide period, creating a cause for concern about potential future conflict. Consequently she sees a great need to put measures into place within the education system to build peace rather than create tensions.

The final article in this issue, by HyeJin Kim, Kurt D. Moses, Bosun Jang, and Annababette Wils, is a case study on the reconstruction of primary education in Southern Sudan (2006-2009). The authors analyse the effects of the reconstruction and the challenges faced. Of particular note is their finding that people living in the conflict-affected areas place a very high priority on their education. This finding corresponds to the message the 2011 GMR is sending: international aid must place a higher priority on the education of displaced persons and respond rapidly to the increased demand for education as a main tool for reconstructing countries and building peace.

This special issue on Education and Armed Conflict provides an in-depth view into various country contexts, and also highlights several issues affecting education in conflictridden areas. The articles offer varied theoretical and practical perspectives on failures, as well as examples of good practice. This issue provides a poignant and thought-provoking reminder of the four failures of humanitarian aid as put forward by the 2011 EFA Global Monitoring Report: protection, provision, reconstruction, and peacebuilding.

Acknowledgments My special thanks to Maria Low for her significant contribution to the writing of this editorial. 